\title{
夜空を拓いて 半世紀
}

\author{
正会員 野間 聖 明*
}

\section{1. は じめに}

飛行機は満月の夜しか飛べないのか，それとも暗夜でも 安全に飛べるのか，と新聞記者から質問ぜめにされたの は, 昭和 7 年 4 月 21 日, 満月の午後 8 時 8 分にフオッカー $3 \mathrm{M}$ 機（225馬力× 3 ）で, 東京飛行場（現在の羽田）を 離陸し, 翌 22 日午前 2 時 42 分に北九州の大刀洗陸軍飛行場 に着陸して夜間郵便飛行のテストを終えた，小川寛爾一等 飛行機操縦士の記者会見の一こまであった．

このよらなことが真剣に議論された時代から半世紀, 夜 間飛行が日常茶飯時のこととして行なわれるよらになった かげには,「かがり火」から航空灯火システムに発達して きた航空灯火の輝かしい発達史があった。

\section{2. かがり火たいて離着陸}

飛行場照明なんて，そんなしゃれた言葉などなからた大 正 6 年 1 月 6 日夜, 伊藤音次郎は千葉県稲毛海岸 (潮が引 くと飛行場になる）で, 潮が引くのを待って助手の山縣豊 太郎と佐野清三郎に手伝わせて, 伊藤式恵美 1 号 (グルゴ アジップ45馬力）を引き出し，かがり火をたかせてその明 りで離陸, 右旋回して上空から見るかがり火は地上で見る のと違って，「なんて人恋しい感じがするものだな」と思 いながら着陸経路にはいりまだまだと思って機首を起こ さないららに早い速度で接地してしまった。

やはりかがり火の明るさでは，着陸の高度判定はむずか しいなあと思いながら，幸いどこもこわれなかったので再 度試み, そして 3 回目にはかがり火の明るさでもスムーズ に着陸することができた。

これに力を得た音次郎は, 真のやみ夜に飛びたい, それ には明るい電灯が汇しいと考えていた。これが日本民間航 空史上初の夜間飛行であった。

伊藤音次郎は，上空から見るかがり火に人恋しさを感じ たのは,「ようし空港だ」という現在のパイロットの航空 灯火に対する感情に相通じるものであって, 物理量として のアビオニックスの精密さに対する, 感覚量としての航空

\footnotetext{
† Half a Century of Night Sky Illumination
}

* 日本航空機操繸士協会 Takaaki Noma

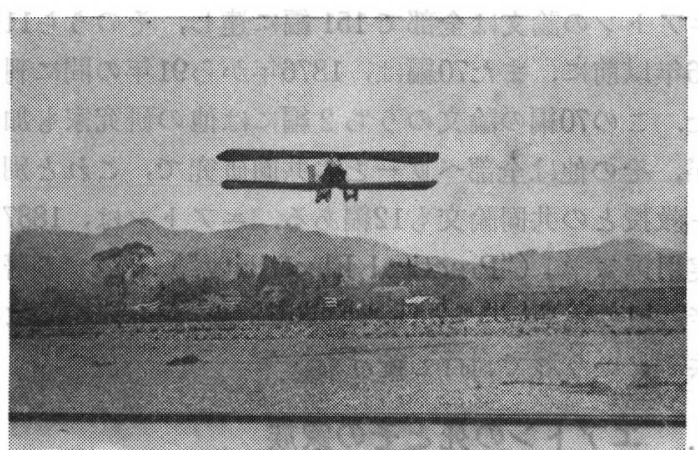

図 1 民間最初の夜間飛行に成功した 伊藤式恵美 1 号

灯火の暖かさである.

これよりさきに陸軍では, 大正 2 年11月15日, 名古屋城 北練兵場で行なわれた大演習で，モーリス・ファルマン機 がかがり火を頼りに夜間着陸を敢行したのが最初である. これから恵美 1 号までは, 夜間飛行のできるよらな機体で はなかったので，夜間照明としてはかがり火以外には考光 られていなかったのである.

\section{3. 外国機の刺激}

大正 5 年 1 月 8 日伊藤音次郎によって, 稲毛海岸から帝 都訪問往復大飛行が行なわれた. 今の国電より遅い恵美 1 号であるから約 1 時間かかることになり, ぶらーがしゃん 時代（飛行機はぶらーと着陸するとすぐがしゃんと墜落す る意味）のころにとってはまさに一大壮挙であったが，何 しろ当時の操縦席は胸から上は気流に吹きさらしのため, 寒さしのぎに酒の一合瓶を持って離陸し, 帰路に一気に飲 み干して稲毛に無事着陸した。途中あわや不時着といら場 面もあったが，酒で暖を取りながら飛ぶよらな古きよき時 代でああったわけである。

このころから外国飛行家の来日がしげくなり，米人チャ ルース・ナイルス, アート・スミス, 女流飛行家カザリ ソ・スチンソン嬢(19歳)などが, 各地に巡業公開飛行を行 ない, 発煙筒をつけて空中文字を画いたり, 夜間飛行の宙 返り, 両翼端からマグネシウムの火を噴きながら,かがり 火の間に着陸したりして航空界を刺激した。. 特に19歳の美 人飛行家の夜間飛行には, ことのほか刺激を受けた音次郎 も, 女になんか負けられないと夜間飛行に踏み切ったので 
ある。

しかし，かがり火ぐらいではとても着陸の高度判定など できようもないが，満月ならば上空では何とか山のシュリ エットぐらいはわかったので，それだけでも非常に力強く 感じていたので, 昭和の中ごろまでは夜間飛行には月秢を 調べて計画されたものであった。「満月なら」といら気持 ちは終戦までパイロットの心の底深く宿っていた，それほ ど暗いということは大きな障害であり，十分な夜間照明が なかったことも原因して，夜間飛行は遅々として進まなか った．伊藤音次郎の「明るい電灯が欲しい」という願望 が，その間の事情をよく表わしている。

\section{4. 航空摇籃時代}

船舶の航行灯や灯台の発達によって, 飛行場灯火の光学 系やレンズ系の技術は確立されたと思われる，乞して大正 8 年には, 日本光機工業では航空機着陸目標灯の特許を得 て製作にはいり, 所沢陸軍飛行学校に納入されて夜間の離 着陸訓練に大いに効果を上げ, 時代の要求に沿って発達し ていった.

一方民間では, 朝日新聞社を母体とする東西定期航空会 社が大正 11 年末から, 東京 (州崎), 大阪 (城東練兵場) を起点として定期飛行を開始し，日本航空輸送研究所も同 年に水上機による界一高松間の定期飛行を開始した.

しかしこの時代は軍, 民共にまだ本格的に夜間飛行がで きるまでの装備はなかった。

昭和 3 年 1 月に国策会社日本航空輸送株式会社が設立さ れ, 昭和 4 年 4 月 1 日には派信省が立川陸軍飛行場内に東 京飛行場設置の告示を行ない，本格的な定期航空が開始さ れ, 翌昭和 5 年には当時世界的に定評のあったフオッカー $3 \mathrm{M}$ 機（8 人乗り）によって, 航空路も大連まで延長され た.

この飛行機が，昭和 7 年に夜間郵便飛行のテストに使用 されることになり,やっと操縦席内にスポットライトがつ き, 計器に夜光塗料が塗られ, 翼端に航行灯尾部に尾灯が つき夜間飛行の装備が整ってきたが，着陸灯はもらすこし 後に装備されることになる。

\section{5. 羽田に東京飛行場開設}

昭和 6 年 8 月 21 日に羽田に東京飛行場が開設され，民間

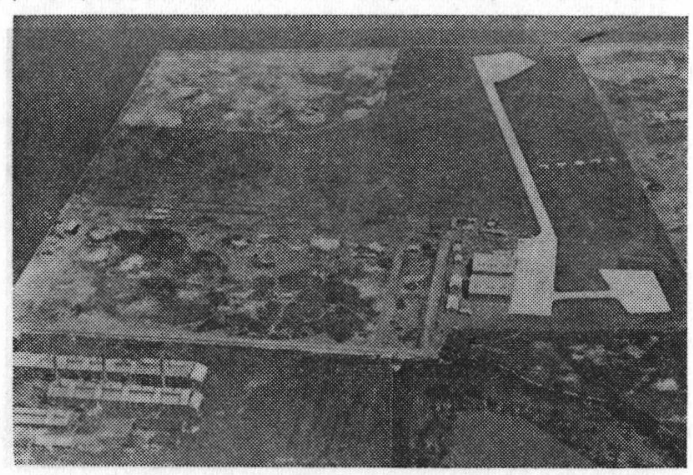

图_2 2 昭和 6 年開設当時の東京飛行場 (現羽田空港)
航空の拠点が立川から羽田に移り, 本格的に民間航空発展 時代を迎光ることになった．その当時の広さは 16 万坪で, そのうち南北の滑走路（幅 $10 \mathrm{~m}$ ) と誘導路, エプロンが 補装されて図 2 のような姿でオープンした.

一方大阪では，これより早く昭和 4 年 4 月に木津川尻の 大阪国際飛行場が完成されていて, 昭和 8 年の夜間郵便定 期は羽田一木津川尻の間で行なわれることになる.

日本航空輸送株式会社では, 羽田移転当初から夜間郵便 飛行の計画があって, 昭和 7 年 4 月からテスト飛行が行な われたのは巻頭に書いたと扣りである.

夜間のテスト飛行が終了すると, 航空灯台の設置位置な そ゚について現地調査が行なわれ, 東京一福岡間で 40 箇所の 設置計画が立案された. 航空灯台は高光度が必要なことか ら, レンズは直径 $75 \mathrm{~cm}$, 焦点距離 $37.5 \mathrm{~cm}$ のフレネル レンズが用いられて, 光源は $1 \mathrm{~kW}$ の白熱電球, 光度 300 万燭光, 鉄塔の高さ $15 \sim 24 \mathrm{~m}$, 拡散 $3^{\circ}$ の光芒であったの で，晴天暗夜には随分遠くから望見できたものであった。 そして日本光機, 東京電気 (東芝), 東京計器, 小系製作 所の 4 社に発注された。一方小型航空灯台は屈折レンズ形 で光源は $1 \mathrm{~kW} 120$ 万獨光で, 東京, 大阪などのビルの屋 上に設置された，これら航空灯台の位置をよく知っている ことが視認するための大前提であった

その後大阪以西のコースは, 途中の不時着場が使用でき なくなったことから打ち切られて, 結局, 東京一大阪間で 行ならことになり，途中の不時着場は三保の松原, 浜松と 明野の陸軍飛行場が使用されることになり，航空灯台 25 籄 所, 飛行場照明 2 箇所, 不時着場照明 3 箇所の設備費用総 額は当時の金で39万円余であった.

ここで特筆すべきことは, 井上正鑑なる人物は一等飛行 機操繸士で乗務していなが，航空局の児玉常雄技術課長の 指示により，地上に和りて運航業務を担当していた．結局 彼は航空灯台や飛行場照明の設置について, 操縦士の立場 と運航業務の立場の両面から, 積極的に裏方業務に徹して 夜間設備を完成に導いたことである。航空界ではいつの時 代でも彼のように両面のできる人物が必要である.

\section{6. 東京飛行場の夜間設備}

昭和 7 年月11日28には伊豆の十国峠に，フレネルデオプ トリック形大型航空灯台が完成し, 翌昭和 8 年 5 月 6 日《

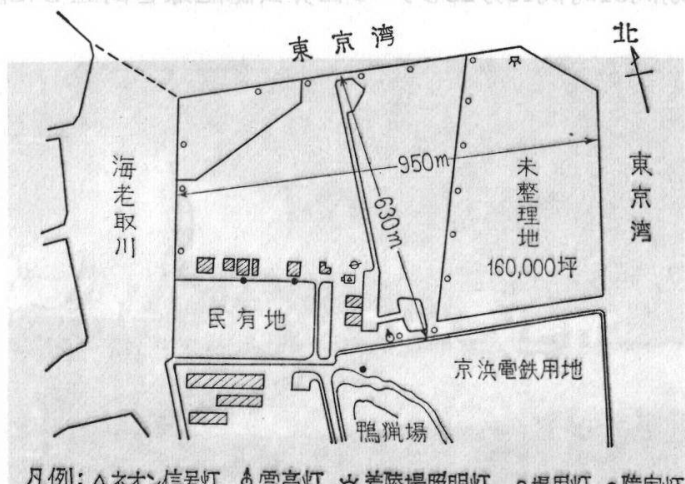

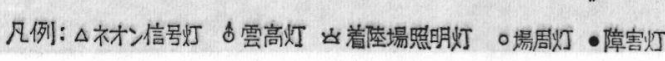

図3 東京飛行場夜間設備配圆图 (昭和 8 年) 
は東京飛行場に 図 3 のよらな夜間設備が完成した。

(1) 着陸照明灯（1 基）

これはスペリー式直流カーボンアーク灯で 160 万燭光, 光芒は水平に $180^{\circ}$, 垂直に $4^{\circ}$, 半径 $600 \mathrm{~m}$ 以内が $3.51 \mathrm{x}$ 以上の照度になり, 図 3 のよらに南向きに設置されたの で，北向きに着陸するときはまぶしかったよらである.

スペリーの光にはちょっとした小話があって，男がこの 光に当たると子供が生まれなくなるとう，もっぱらのら わさがあった：子供の生まれないパロットが奥さんに， スペリーの光の中を通ったのでと，いいわけをしていたも ので，女遊びが過ぎた理由をスペリーの光のせいにしたも ので真偽のほどは定かではない，

\section{(2) 信 号 標識 灯 (1 組)}

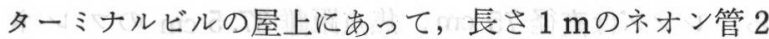
本を直列にしたもの 2 条を一辺とする正三角形を作り, 各 辺の色を赤, 青, 橙として, これらの点隇によって発着の 可否，風速などを飛行機に知らせたもの.

(3) 雲 高 標 示 灯 ( 1 基)

これをわれわれは「らんだか・ひょらじ」といった。そ のほうがいろいろと妙な誤解を招かないはす゚である. エプ ロンの南側に設置され, 垂直上方に光芒を出す投光器で $150 \mathrm{~m}$ 離 れた点から雲底の高度角を測定したものであっ た.

\section{（4）場 周 灯 (15灯)}

飛行場周辺に沿って 約 $100 \mathrm{~m}$ 間隔で， $60 \mathrm{~W}$ の電球を橙 色のグローブで覆って, 地上 $30 \mathrm{~cm}$ のポールの先につけ た全方向性の地上形灯器であった. 当時はこの程度の照明 で十分飛行場の輪郭がわかったものである。

\section{(5) 障害灯 ( 3 灯)}

飛行場に隣接する電柱の上に $60 \mathrm{~W}$ の電球をつけ, 赤色 のグローブで覆ったもので，鴨猟場の北側と民有地との境 界線の電柱に設置されていた。

以上の設備が占めて 40,552 円 98 銭であったが，さらに昭 和10年には風向標示灯 1 基, 補助着陸照明灯 2 基, 投光器 6 個，障害灯40灯が増設されたが，まだまだ十分な夜間照 明設備とはいえなかった

昭和 12 年 4 月 6 日に立川から出発した朝日新聞社の神風 が，東京一ロンドン間 $15,357 \mathrm{~km}$ を 94 時間 17 分56秒（実 飛行期間51時間19分23秒）の世界公認記録を樹立した際に

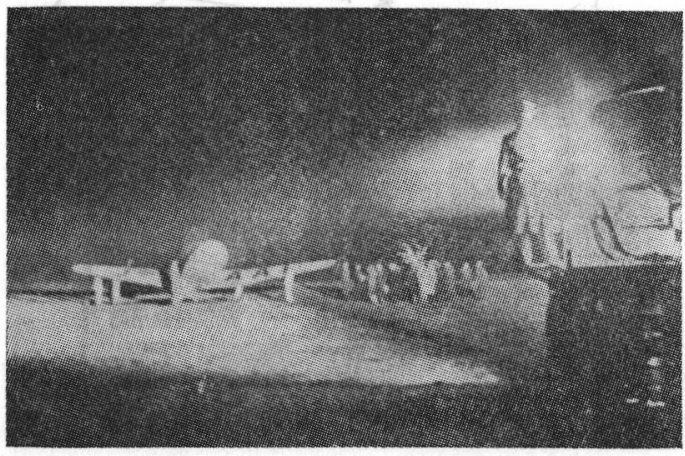

図 4 立川から壮途についた神風
は, 命名・出発式だけが東京飛行場で行なわれて立川から 出発した.このような記録を狙った長距離大飛行では出発 が深夜になり, 東京飛行場の広さや照明設備では不十分で あったので，立川から 4 月 6 日午前 2 時 12 分 4 秒にスペリ 一の光芒の中を壮途についた（図 4).

着陸照明のスペリーは右後方から照射すると，左前方を 見て離着陸をやるパイロットの目に，自機の影が地面に写 るのがよく見えて高度判定が楽にできるのである.

続いて昭和 14 年 8 月 26 日には，毎日新聞社の「ニッポ ン」号の世界一周親善大飛行の際は, 東京飛行場も滑走路 が 2 本になり, 面積も 1.4 倍に拡張されたので国を埋めた 日の丸の歓呼の波に送られて堂々と出発していった.これ で東京飛行場も一応，名実共に日本の表玄関としての設備 が整った。この時代はまだ滑走路が今ほど重要視されてな いので滑走路灯や中心線灯は設備されてなかった（図 5).
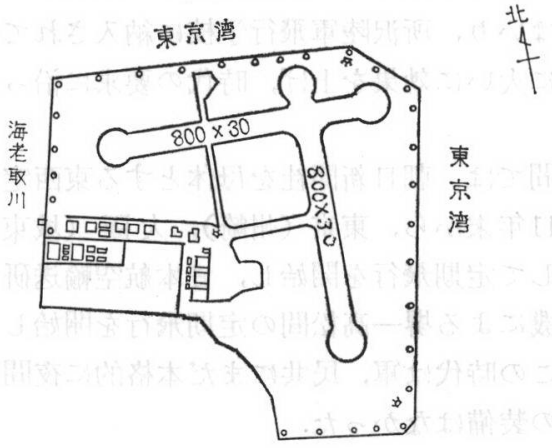

図 5 昭和 14 年当時の東京飛行場 (羽田) (滑走路には灯火設 備はなかった）

これから巨大な歴史の流れに乗って, 大陸戦線の拡大に つれて航空灯台も朝鮮，満州にまで設置され，航空路も羽 田を起点として大陸や南方に延長されて, 国内でも伊丹, 名古屋, 福岡第一, 調布, 那覇, 米子, 仙台, 札幌の各飛 行場の夜間照明施設が整備されていく.

\section{7. 夜間郵便飛行}

日本航空輸送株式会社は, 昭和 8 年 1 月に中島飛行機製 作所に夜間郵便機 8 機を発注し， ほかに同型の義勇九州派 信号を加えて 9 機になった。 中島では 90 式 2 号水偵 3 型を 改造して, 着陸灯, ラジオビーコン, 送受信用無線電話,

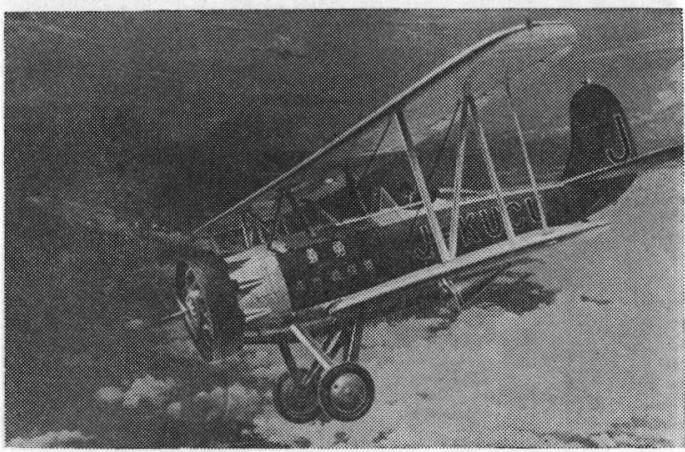

図 6 夜間飛行中の中島 $\mathrm{P}-1$ (翼下面に着 陸灯がある） 
照明弾を装備し, 郵便搭載量 $300 \mathrm{~kg}$, 最高速度 $240 \mathrm{~km} / \mathrm{h}$ の, 当時の単発機としては最優秀装備の夜間郵便機となっ た.

最初に, 中島 $\mathrm{P}-1$ で夜間飛行のテストと訓練が東京飛 行場の照明灯が完成した昭和 8 年 5 月 6 日に行なわれ, 大 阪でも同じように行なわれて，9月下旬には相互に乗り入 れ往復飛行訓練も終了して, パイロットは夜間飛行専任操 縦土の辞令をもらって11月 1 日を待った. これで飛行機, パイロット，航空灯台，夜間照明などがすべて準備完了 し，満をじして11月 1 日を待った。

待らに待った 11 月 1 日は雨のため, 第 1 便は 2 日に延期 されて, 飛行場には片岡航空局長, 戸川, 松永両重役以下 会社幹部の見送りを受け，200万燭光の航空灯台，400万燭 光のフラッドライトを始め, 各信号灯が一斉に光を放つ中 を 5,000 通の郵便物を積んだ中島 $\mathrm{P}-1$ に，パラシュート 姿ものものしく機上の人となった鳥居一等飛行機操縦士 は, 午後 6 時 17 分大地をけって離陸, 途中箱根の難関も無 事突破して 9 時24分大阪に着陸して, 途中点々と輝く航空 灯台, 街の灯は何ともいえない美観であったと述べた.

大阪を午後 6 時に離陸した上り便の豊島一等飛行機操縦 土は, 郵便物 3, 700 通を積んで快翔, 箱根の難関は肌に汗 を覚えながら見事に突破して午後 8 時 1 分東京に着陸. わ が国最初の夜間定期郵便飛行は大成功に終わり, 関係者一 同祝杯をあげた. 今と違って箱根, 丹沢, 鈴鹿, 伊吹山は 名だたる空の難所で, 航空灯台も設置されていたが遭難も 多く先輩の苦労がしのばれるところである（図 7).

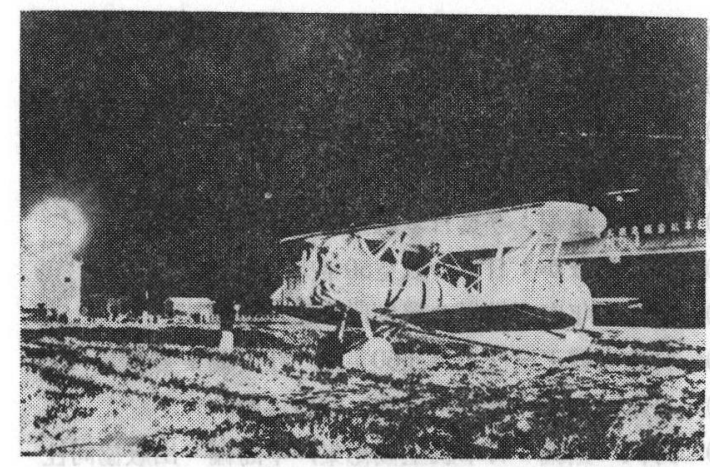

図 7 大阪国際飛行場出発前の中島 $P-1$

この図 7 では，50年前のエプロン照明の様子がよくわか る. 2 方向からこうこうと照明された $\mathrm{P}-1$ の姿である. 昨年11月25日の「航空照明50周年を記 念するつどい」 で, 元夜間飛行専任操縦士であった岡本德次氏の懐古談を 聞くと，着陸照明灯は十分に着陸帯に届かず，その上照明 灯に向かって着陸するとまぶしくて困った. P-1には着 陸灯があったのでこれがいちばん役に立ったとのこと．筆 者が昭和15年ごろ使用したスペリー照明灯は移動式で，む っと進歩していた. 岡本氏の話しでは途中の不時着場に着 陸した場合は，まず地元の郵便局に郵便物を渡し，飛行機 を繫留して長距離電話連絡で指示を仰ぎ宿についたが，た った 1 人で革の飛行服の上に救命胴衣とパラシュートをつ け，飛行帽をかぶっていたのでたいへんであったとのこ
と，無線電話は飛行場をすこし離れると全然通じなくて， 天候判断やその他の連絡に苦労が多かった様子であった. 単座機による夜間飛行は不便が多く, 気象の急变による 危険も多く, 搭載量の不足などから $\mathrm{P}-1$ の利用価值が下 がっていたとき, 支那事変勃発による大陸方面への航空路 の延長に伴い燃料, 乗員の関係も窮屈になったので, 夜間 郵便定期は中止されたけれども，飛行場の夜間照明は毎夜 点灯されて大型機の長距離定期飛行の発着に利用された.

\section{8. 限りなき前進}

昭和13〜15年にかけて東京飛行場は，16万坪から 22 万坪 に扛張され, 滑走路も $800 \mathrm{~m}$ のの 2 本になり, 照明施設 も新型灯器の使用, 合理的配置, 遠隔操作が行なわれ, 続 いて国内各地の飛行場も昭和19年ごろまでに整備されて, ハード面では確かによくなったけれども，灯火の持ってい る情報は少なくて, 位置, 範囲, 方向, 明るさぐらいの情 報しか持ってなかったので，新しい型はしていても機能と しては多分にカンテラ的であった.

だから図7のように明るい灯火をぱっとつけると, 遠く からよく見觉る代わりに, 途中の物体の視認性が悪くなる 現象がでさ，ゲん惑されることもあって，衝突したり滑走 路の手前に着地したりする事故が後を絶たなかった. 航空 灯台は遠くからよく見えたけれども, 十国峠などの山岳地 帯にある場合は, 飛行機との高度差が少ないため手前の山 が非常に見えにくい現象が，衝突事故の原因になったこと もあった.このよらな灯火の生理的, 心理的な面からの見 え汸ついて気がついたのは戦後になってからである.

現在の航空灯火は, 灯火パターンを構成して昼夜の別な く積極的に連続して情報を提供し, 航空機の運航を促進さ せるものであるから, パイロットの中心視野の近くに設置 されるよらになったので, 特に灯火システムの見え方の研 究と照明心理生理の研究がたいせつであり, それを運航関 係者, 特にパイロットに徹底させる教育が必要である。

以上のアイデアのめばえは, 昭和 15 年ごろ陸軍で使用さ れた簡易標灯着陸方式に現われていて, 現在の自動着陸の 理論に通ずるすばらしいもので, 滑走路末端近くに高さ 5 mの棒の先に 1 灯をつけ, その前方 $100 \mathrm{~m}$ の地面に数灯を 横に並べこれを一線に見通して降下すると $3^{\circ}$ になる. その直前でさらに前方を見ると，3〜 $4 \mathrm{~m}$ の棒の先に 1 灯 があり，その前方に同じ高さの横に並んだ枠の上に10灯ほ ど並べて，これが同じ高さになるように機首を起こすと着 陸でさるものであった. 特に急な降下を行なら航空母艦の 着陸誘導もよく似た方式が使用されたが, 着陸の進入角の 設定情報, 着陸操作情報を伝達する最初のものであった. このような情報を伝達する灯火パターンを構成すること が, これからの航空灯火システムの最終目標であろら.

日本では終戦で航空灯火施設も壞隇したが, 翌昭和 21 年 には米軍の命令によって, 既設の航空灯台の撤去と新な位 置への移設工事が始まり，さらに航空障害灯の製作と設置 が行なわれてようやく関係者を喜ばせた. 


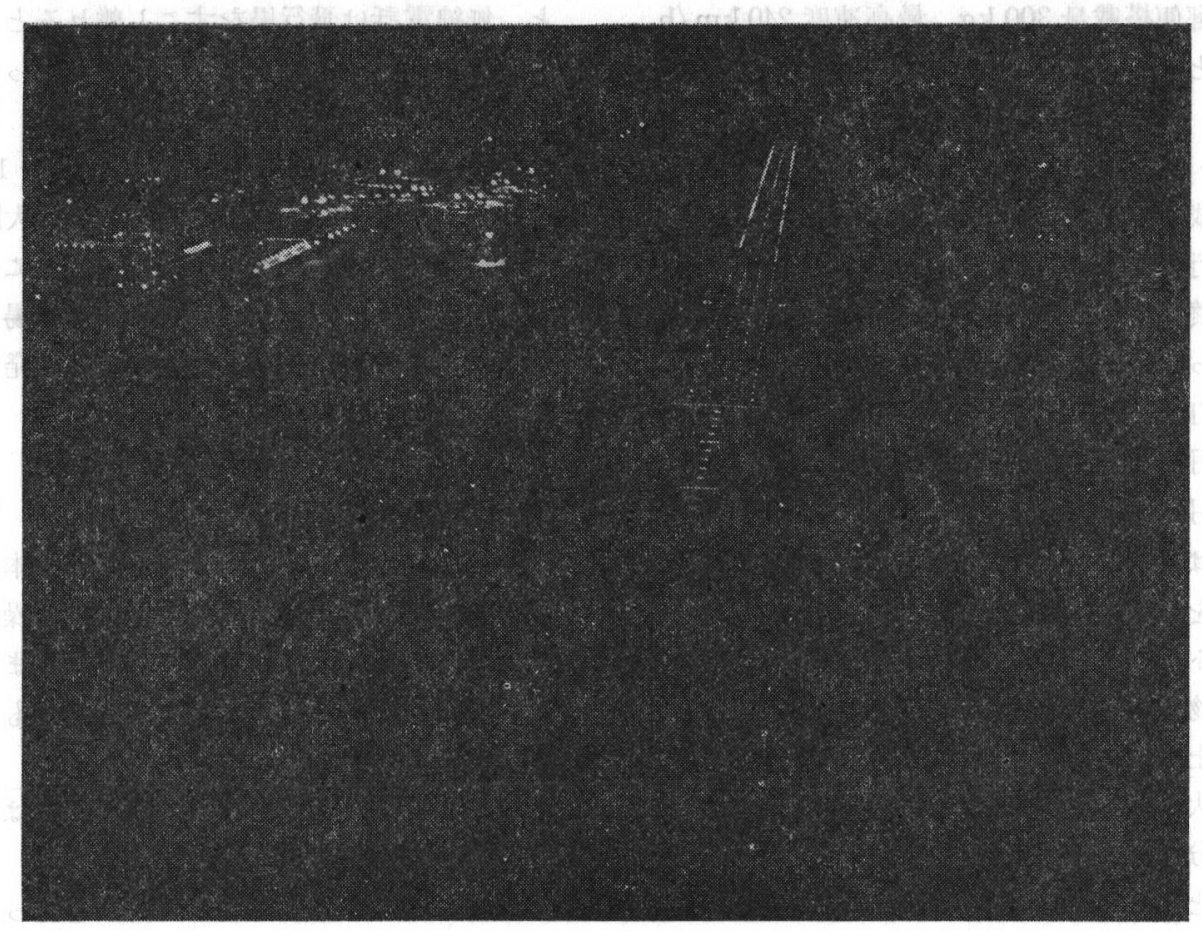

図 8 成田空港 RWY 16から見た夜間照明 カルバール式アプローチライトがよくわかります。

続いて日本光機工業により, 小牧飛行場の照明一式が製 作・施工が行なわれ, 航空照明の分野も本格的に活気を带 びてきた. 昭和 30 年代になると色光によって情報を伝達す る VASIS (進入角指示灯) が導入され，それが PAPI (Precision Approach Path Indicator) へと発展したの である.

同じく30年代にジェット化が行なわれ，埋込久形灯火や 高光度灯火が多くなり, 航空灯火関係の進歩は早く安全性 や保守性の面からも，モデルチェンジは 5 年単位で変わっ ていく感じである. 時代は PAPI からさらに PLASI (Pulse Light Approach Slope Indicator) に進みつつあ るのだから.

また照明学会に呿ける航空灯火関係の研究, 調查, 開発 子昭和 43 年から 21 件を数党現在続行中である.

戦後ゼロから立ち上がった航空照明も, 世界的水準に並 ぶところまで進歩した裏には, 航空局, 空港公団, メーカ 一各社，たくさんの空港を支觉てきた人々の努力を忘れて はならない，その成果が図8 の新東京国際空港の夜間照 明設備である。

\section{9. おわりに}

いくらアビオニックスが進んでも, パイロットは雲下に 出て進入灯や滑走路灯を見たときには，「漂っと」するも
のである.これが灯火の暖かさである.

だから灯火パターンは消えてはならないのであり，パイ ロットは見方方について研究して，錯覚や錯視に陥らない で見方方をうまく利用することがたいせっである.

参考文 献

（1）平木国夫 : 空気の階段を登れ 朝日新聞社

（2）平木国夫：イカロスは翔んだ 国際情報社

（3）平木国夫 : 羽田空港の歴史 朝日新聞社

(4) あいらの航空史 中日新聞社社会部

（5）野沢 正編：写真日本航空50年史 出版協同社

(6) 郡 捷淰か：日本の航空50年史 酣燈社

(7) 航空70年史 (世界の翼別冊) 朝日新聞社

（8）日本光機工業株式会社60年史 社史編集委員会

(9) 日本航空史 (昭和初期編) 航空協会

（10）野沢 正編：日本航空機総集, 中島編 出版協同社

(11) 小川利彦：日本ヒコーキ大図鑑 講談社

(12) 航空照明50周年記念のつと゚い資料

(13) AIRPORT REVIEW 国際空港ニュース社

(14) 水木 清 : 着陸と眼 航空医学実験隊

(15) 成田空港夜間空中写真 新東京国際空港公団

(16) 野間聖明：MAN-MACHINE 時代を考光る 航空協会

（受付1984年 1 月 5 日） 